\title{
Tasawwuf-oriented Educational Philosophy and its Relevance to the Formation of Religion and Ethics Course Curriculum
}

\author{
Mizrap Polat \\ Faculty of Education, Eskişehir Osmangazi University, Turkey
}

Copyright $(2017$ by authors, all rights reserved. Authors agree that this article remains permanently open access under the terms of the Creative Commons Attribution License 4.0 International License

\begin{abstract}
The breadth of the symbolic, linguistic and practical articulation of Tasawwuf philosophy includes concepts pertinent to education. Tasawwuf distinguishes itself as a site for the development of moral sensibility and mindfulness $(\operatorname{taq} w \bar{a})$, as an intellectuality recognizing the sense and purpose of faith (hikma and ma'riffa), and as a creator/creation-observant consciousness (ihsān). Tasawwuf includes among its pedagogical aims cognitive and spiritual development, a religious and moral sensibility, and socialization. These ambitions are served in as far as no distinction is made between natural, social and religious areas of education, but rather all are seen as a collective foundation for the accumulation of knowledge. This article addresses the question of whether and how Tasawwuf as an educational perspective and teaching tool is considered within religion and ethics course curriculum within Turkish secondary schools (High Schools, namely Lise). The conclusions demonstrate the opportunity to link Tasawwuf-influenced educational concepts and contemporary educational philosophies, resulting in an innovative re-reading of authentic Islamic educational ideas. Findings of curriculum analysis indicate that such a connection is rarely established.
\end{abstract}

Keywords Educational Philosophy, Tasawwuf Philosophy, Values Education, Religion Course Curriculum, Ethics Course Curriculum

\section{Introduction}

The terms "Tasawwuf" [10] and "Sufism" [6] are commonly used interchangeably, a practice I will follow in this text. While Tasawwuf emphasizes the theory and philosophy of Islamic ethics and intellectuality, the term Sufism accentuates the practical side of Islamic piety, religiosity and morality. However, as these components are so integral to one another, it renders a division of the two neither sensible nor practically possible [11]. Tasawwuf (Sufism) describes the inner or cerebral world of interpretation as it refers to the physical (related to the senses), as well as intellectually perceptible, concerning itself with the joining of the sensual with the transcendental. Tasawwuf is certainly more than the spirituality of the contemporary late modern period, seeking an interpretation beyond transcendence. Such an analysis is simultaneously one of life and the world: intellectually, mentally and actively describing the relationship between an individual and God, humanity, and nature. It is an interpretation that provides a spiritual as well as functional orientation of the self in the universe; an ontological and social search for identification, and finally, a multifaceted dialogue regarding the quest for identity. A Tasawwuf-influenced education ('Irfān-Education) invites wisdom, insight and piety into the acquisition of knowledge, whereby such piety does not end at the border of a particular sort of confessional theology, but rather stands for universality and inclusivity.

\section{Method}

The main question of this study, which has a qualitative research feature, is how Sufic educational philosophy reflects and should reflect today's educational thought and curriculum. The main strategy of the study can be summarized as follows: the first was the systematic determination of the idea of Sufic philosophy's interest in education through the examination of relevant sources. Second, the data obtained as a result of this examination was reinterpreted according to current educational curriculum and contextualized within teaching programs. For this purpose, books by individuals including al-Ğurğānī, an-Nasafī and Ibn 'Arab̄̄, and al-Ġazzālī, which stand out when discussing the dimension of education theory of Sufi philosophy, were examined and interpreted through a 
content analysis method. The content analysis method is based on a systematic review and interpretation of the source to determine its judgments, meanings and ideas [2]. In addition, the views of classical Islamic philosophers such as al-Fārābī, Ibn Sīnā, and Iḩwān aş-Şafa (a group of $10^{\text {th }}$ century scientists) have also been consulted and these approaches will be discussed.

The Qur'an and the Hadiths, important sources of Islamic educational imagination, have also been applied as an attempt to provide diversity and multidimensionality. Attempts have been made to create a multidisciplinary approach to understanding by referring to these sources. In the context of utilizing the Hadiths, reliable sources of Hadiths such as al-Buhāāī, Muslim, Abū Dāwūd have been applied.

Spiritual and emotional education, which is neglected in today's religious and moral education and training, is prominent in Sufic educational thought and practice. The reflection of such learning approaches, still pronounced in Sufic curriculum of today, is also. In this respect, this study, which interprets Sufic educational philosophy according to contemporary educational thought and applies it to Turkey's "High School Religious Culture and Ethics Course Curriculum" [Lise Din Kültürü ve Ahlak Bilgisi Ders Porgram1], is a case study. Studies that examine a program in detail are also within the scope of the case study [5]. The data obtained from the "High School Religious Culture and Ethics Course Curriculum" with the help of the document analysis method have been interpreted both within the framework of Sufism and modern educational philosophy. Data obtained from curricula in educational research studies is seen as significant [30]. The reason for the selection of the "High School Religious Culture and Ethics Knowledge Course Program" for analysis is that this program is one of many that directly and indirectly address issues of Sufic thought in the most formal school programs in Turkey. A critical look at the sources of educational philosophy has been referred to for the validity and reliability of the research. In addition, attempts have been made at increasing said research validity and reliability through the use of multiple qualitative research methods and written sources. The method and resource types are items considered to enhance the reliability of a qualitative study [22].

\section{Discussion}

\subsection{Approaches of Tasawwuf Philosophy in the Religious and Ethical Educational Traditions of Islam}

According to Sufic understanding, it is possible for the knowledge attained and understood via the sensory organs to be connected to and interpreted along with the transcendental. An open boundary is generated from the basis of this awareness between information ( $m a$ qūmāt), knowledge ('ilm), perception ( $\operatorname{irfān})$ [17] and profound comprehension (hikma) [10]. On the one hand, this permeable boundary makes dialogue and interaction between the sensual (empirical/cognitive) as well as transcendental production of information (ilhām/kašf) [10] and that which is possible to articulate verbally, and on the other, that which is not. The Muslim Sufis perceive an indivisible connection between belief (ìmān), knowledge ('ilm) and reason ('aql) [6]. Reason and knowledge are for them inseparable prerequisites of an individual's capacity for faith [31,9]. Ibn Sīnā (Avicenna) envisions liberation as the objective of education. The human who secedes from the trappings of worldly dependencies as well as personal interests to devote themselves to the exclusive pursuit of God's truth (Irfan [ $\left.{ }^{i r f a ̄ n}\right]$ ) may be named Arif ('ārif: one who has reached awareness, the wise). Therefore, it is the attainment of the status of Irfan that is considered the greatest freedom [17]. The Sufis believe the soul to simultaneously be the source and matter of the discovery of knowledge and wisdom. In order to locate oneself ontologically, intellectually and morally in one's surroundings, an individual requires a conscious and distinguishing view and orientation. Furthermore, these qualities are also needed in categorizing, reflecting on and rectifying their status $(h \bar{a} l)$. Such a reflection poses the following question to an individual: "How should I, an attentive, responsible and just person with my particular knowledge, abilities and capabilities, conduct myself in relation to nature, both animate and inanimate?" This question contains a values orientation that implies a principled education as a pedagogical task. The famous Sufi Haci Bektaş Veli views this values orientation (virtuousness) as a convinced and convincing religiosity. He believes in a direct correlation between morality and proximity to God (or observance of God) [14]. Thus, there shall be a justification that religious and ethical education should go hand in hand. Moreover, the philosophers Fārābī and Ibn Sinna assert reason, intelligence and knowledge to be the basic principles of human perfection. Both philosophers consider these factors the most important conditions for the moral integrity of an individual. Fārābī and Ibn Sīnā implore that those in a virtuous society who are given decision-making abilities and carry responsibility should be either prophets or philosophers, as both groups simultaneously exhibit the highest moral code, extensive understanding and acute intelligence $[8,18]$.

According to Sufi-oriented religious and ethical education, it is not of paramount importance to prove God's existence or to use this fact as an article of knowledge. Instead, God is to be believed as truth and reality, to be trusted along with one's own respective acts as a human in view of God, and that all interactions with all creation are characterized by great prudence and respect. This is the intention for religious and ethical education: the guiding of humanity through God. In this way, such an education is qualified as an integral if not inventing aspect of the human 
biography. The Muslim Sufi Ibn 'Arabī or al-Balyānī [15] (the author of the book cited here is disputed) states that God's uniqueness and wholeness are the veil distancing him from human comprehension. It is for this reason that Tasawwuf places at its core the perception and experience of God through human thinking, feeling and action, instead of a conventional theological and segmented description of God. Among further names and attributes, God is truth and the one who induces truth (al-Haqq), he is justice (al- $\mathrm{Adl}$ ) and the One (al-Wähid) [23]. The substance of the previous attributes "truth," "justice" and "unity" belong not to God's own self-presentation but equally dictate God's demanding and supportive expectations addressed to humanity as they aspire for truth and awareness of unity among all creation, realizing equity while maintaining a gracious demeanor.

Irfān (perception) refers not only to a relationship with God and humanity but to learning to recognize, know and value oneself. Such self-awareness promotes mastery of the self, an awareness attained through the sensibility to personal deficits. In this way, irfän-oriented (Sufic) education can be interpreted as a capacity for self-discovery and development, as well as a competence in religious and ethical education.

Competence orientation is generally a current topic of discussion in religious pedagogical circles [28, 12]. However, two termini are significant in the Islamic approach to religious and ethical education, particularly in relation to the description of competencies within Islamic religious classes:

Taqwa $(\operatorname{taq} w \bar{a})$ : the Taqwa, which in a sense describes heedfulness and reverence to God, further dictates the personal rights and responsibilities to recognize and respect the rights of others, and the recognition of and fulfillment of duties one has to God, to oneself, and to one's contemporaries [10]. The expression "Taqwa," as it refers to conscious responsibility, conveys a significant degree of the Muslim-being, which in turn is a preliminary step toward the maturation point of Ihsan, articulated below (Koran, 2: 1-5, 42-46, 224; 3: 51).

Ihsan (ihssan): This term refers to the condition of an individual who possesses the capacity to perform actions in consideration of the creator as well as fellow creations [10, 6]. An individual who has reached the status of Ihsan is denominated "Muhsin" (muhsin). The Koran also refers to those individuals who regularly demonstrate goodness as Muhsin and praises them (Koran, 2: 58, 195; 4: 125; 5: 93; 17: 23). The Muhsin always endeavor to realize and modify their intentions, feelings and acts in the best and most appropriate manner. This qualification as the good proves to be an undertaking in self-reflection and self-realization devoid of outside coercion and control. Through Ihsan, the internalization of values, compassion, and the process of ethicizing faith can be elucidated. Belief and moral behavior nourish each other in Ihsan. It is not possible for religion to abstain from morality [20], as morality in this case is to be understood as the sense and purpose of religiosity, and humanity in turn as the good and constructive social and/or internal representation of the relational formation. Such an ethically-conformist religiosity can in turn be viewed as socialization, as social responsibility and sympathy (social competencies), as well as other qualities, can emerge as a result. Ihsan as a spiritual maturation point also pertains to emotional proximity to the creator and to a view of oneself in solidarity and unity with all of creation. Preoccupation with creation through human activity is parallel to preoccupation with God in such activities. Islamic piety discerns a deep bond between creator and creation, viewing the creation as a mirror for the power and beauty of God.

At the forefront of the initial definitions of Taqwa stand the exact observance of God's commandments and prohibitions in order to maximize reward and avoid punishment. As expected, an informative and normative realization is conferred here to obey proscriptions and to fulfill obligations. In the case of Ihsan, a further stage is observable: mindfulness stemming from a love of God and creation irrespective of recompense or penalty. The Muhsin relate to God out of a soulful connectedness without the perspective of those who are an existential, ontological part of God, but rather as beings who possess deep love, awareness, attention and communion with God and creation. These characteristics provide the ability to reflect on and improve intention, demeanor and action. The belief in God as all-seeing (al-Bașir) and that all human acts influence judgment in the afterlife is common, particularly among monotheistic religions. The Ihsan-maturation, however, seeks to maintain this faith as conviction and to develop a constant consciousness from it. This consciousness equally implies that the human frees himself from the necessity of an intermediary in the attainment of God's love and goodwill, and from provisions for reciprocal relations to God and fellow human beings, exchanging such perspectives in favor of loving affiliations. These ties require constant attention and usher the way to a religious legitimization of only the good and humane instead of the use of violence or injustice. The Koranic concept of humankind as God's successor (vicegerent [khalif]) on the earth (Koran 2: 30, 6: 165, 27: 62, 35: 39, 38: 26); [26] embodies such a consciousness.

Respect for human dignity and the support of the natural disposition is called Fitra (fitra). The preservation of nature is established as a competence ordered among established meta-competences to view humans as God's trustees (caliphs) of the earth. The Fitra can be understood as an internalized morality and pure, original state of belief before a systemization by theology. The Koran (30: 30) defines Islam as the religion that corresponds to human nature:

"So [Prophet] as a man of pure faith, stand firm and true in your devotion to the religion. This is the natural disposition God instilled in mankind-there is no altering God's creation-and this is the right religion, though most people do not realize it."

The Sunna (remarks, stories and silent acceptance) of the Prophet Mohammed also contains the word Fitra, in the 
sense of the pure and the natural relevance to humanity and the belief immersed within it (the capacity for faith). In the following Hadith it is written (Buhārī, Ğanāiz, 79-80, 92) [4]; (Muslim, Qadar, 22-25) [24]; (Abū Dāwūd, Sunna, 17) [1]:

"Every child is born in accordance with the Fitra. It is only later that they are raised as a Jew, a Christian, or a fire worshipper."

The concept Fitra expresses (among other sentiments) the communal and primal among humans, also in the sense of belief and the capacity for it [3], while maintaining a proximity to the expression "primal truth." When this primal truth is accompanied by humanity's collective disposition and inner guide, along with trust in God and attention to others, and vigilance and sensibility toward injustice, these factors can contribute to the development of a moral and discerning religiosity. Such a religiosity heeds not only the godly but also the human, in that it takes seriously human beings in their ontological dimensions and those accomplishments acquired throughout the history of civilization.

Sufism as an Islamic-oriented piety and intellectuality desires to enrich faith affectively by way of love, mercy and empathy, as well as contributing to the construction of the human achievement in a way that is simultaneously worthy of God and fellow man. It is therefore sensible to assume that the goal of education as defined by Islam should be grasped as a convergence and correlation between religious expectation and daily reality. A group of Sufic philosophers, ethicists and theologians calling themselves I $h w$ ann aș-Șafa (Brothers of Purity), maintain that an education committed only to individual biological urges, economic interests and social expectations is inadequate. They plead for the mental development, moral socialization and religious maturation of a person not to be neglected and wish to avoid a sacrifice of psychological purification in the name of bodily and material gratification [19]. Sufism aspires to be the way (tarīqa) by which people comprehend both themselves and eternal truth. Sufis view every person as microcosm and mirror of this truth. The person on these paths should simultaneously be taken with this truth. Tasawwuf (Sufism) viewed as a lived and intellectually determined purity and spirituality intends for the individual to observe their inner experiences and to appreciate them as a part of one's own religiosity.

A multifaceted strategy for excess resides in Sufism. On a hermeneutic level and beyond a mainstream interpretation of theology, Sufism seeks to interpret and occasionally provide an answer regarding issues of the Koran and the Sunna that orthodox theology cannot supply in the same form, in this way furthering the hermeneutic competencies of religious instruction. The hermeneutic interpretation style of Sufism and its religious performance are occasionally accused by mainstream theology of syncretism. In certain circumstances, this charged relationship intensifies and is exploited. The dissent of interpretation is occasionally only a competition of interpretation between Ulama (religious scholars) and Sufis. The Ulama emphasize the normative side of the religion, whereas the Sufis emphasize an intimate view, although neither completely excludes the other. Such an interpretational difference is sometimes generated in the application of varying hermeneutic methods relevant to the Koran or the Sunna. The Sufis credit God's intuition for their analysis, namely ilhām or išăra, and utilize a symbolic language [7] through which the deeper and encrypted sense (ba tatin) of statements made in the Koran and the Sunna may be revealed. The prominent Sufi Ibn 'Arabī[16] can be referenced as a concise example of this interpretive approach. Conversely, the Ulama incline toward interpreting said source philologically according to the visible/exterior (zähir) sense and according to the meaning of the words. The various categories of the Tafsir (commentary on the Koran) arose out of these contrasting methods, as in the case of the philological (lugiaw $\vec{l}$ ), the transmission-oriented (riwāya), the reason-oriented (dirāya), and the spiritual (išăra) Tafsir.

In its institutional venues for living, experience and learning such as Tekke (takka) and Zawiya (zäwiya), Sufism aims to create a spiritual atmosphere and an intimate connection between man, his faith and his fellow creatures. The educational premises and concepts of Sufism can be summarized as follows: the recognition of the self ( $m a$ ri $\bar{i} f a$ an-nafs), the attainment of awareness of God (ma'rîfa-t-ullāh), love of God (hubb-u-llāh) and his creations, awe of God's radiating love, as well as action that is worthy of God and his creations. These premises have aspects observable epistemologically, affectively and morally and are simultaneously levels of fulfillment of Sufism. The way that man locates himself within the universe should occur by way of self-recognition, self-appraisal (as God's Caliph on earth) and development of consciousness of his relationship to God and his creatures. A Sufic-minded individual sees himself not only connected to Islam, but as brother to all men, created by a single, common creator. Islam in general is understood by Sufis in the most general of terms as "devotion to God." Sufism as a simultaneous site of learning, spirituality, religiosity and morality portrays itself as more anthropological (or student-oriented) in comparison to Madrasa (theological schools and colleges). In the Tekkes and Zawiyas (locations of living and learning of Sufism), people stand ontologically, intellectually and ethically at the center of the pedagogical act while in a more significantly pious and spiritual atmosphere. Regarding the Madrasas, it is rather knowledge and epistemological orientation that form the focus. With its person-oriented pedagogical mindset, it was largely possible for Sufism (Tasawwuf) to even out-equalize the dialogue between religion, spirituality, reason, ethics and philosophy. In a closer reading of the Sufic path as one based on intellectual (sensually interpreted), inner (affective) and plot-oriented (moral) experience, the relatively multifaceted pedagogical possibilities and levels are revealed. It follows 
that with Sufic applications in religious pedagogy, a broader (horizontal) and deeper (vertical) view of topics in religious instruction is possible.

Sufism regards learning as more than an epistemological, didactic interaction between teachers and students, emphasizing the affective relationship between the two. This bond occasionally leads to student disenfranchisement, however in this school of learning and experience, autonomy is perceived differently than most school pedagogies of today [26]. With its institutions and forms, Sufism holds a respectable position in the landscape of educational upbringing. The values-oriented and socially-motivated pedagogical approach intends to prepare an individual both mentally and morally for the capacity to act as and to remain "God's caliph on earth." It is the aim of such a method to maintain a perspective that includes all of creation and to mirror God's mercy and love in regard for the multitudes. After completion of the Sufic education, a person can, by way of this religious instruction, be empowered as the most competent of beings (Koran, 95: 4), in whom God immerses his soul (Koran, 15: 29); who internalizes the godly attributes such as "the loving" $(a l-W a d \bar{u} d)$, "the all merciful" (ar-Rahmān), "the nurturing" (ar-Rabb), "the knowing" (al-'Alimm), etc.; and reflects these qualities in demeanor and deed.

Tasawwuf nourishes itself not through Islamic theology alone, but also through Islamic philosophy. The disciplines of ethics, anthropology, and epistemology have all been intensely reviewed by Islamic philosophers, and the resulting insights have been integrated into the philosophy of Tasawwuf. The Sufis devoted much attention to philosophy and defined the rumination (tafakkur) on existence as a service to God. They formulated their own philosophical questions and developed approaches in accord with their ethos [29]. The particular relationship between philosophy and Tasawwuf favored the high visibility of pedagogically-relevant approaches within Sufic ideas and action. Accordingly, Islamic philosophy-with its relationship to antique Greek, Indian, Mesopotamian and Far Eastern philosophies, as well as the early influence on the development of European philosophy (for example Averroes [Ibn Rušd] and Avicenna [Ibn Sīnā]) — was able to establish the preconditions for Islamic educational philosophy to communicate on an equal intellectual plane with European schools of thought. It can be useful for multiple reasons to treat the scientific and culturally historic relationships and interplay between Islamic and western civilization as an entity for various educational subjects.
Such an intercultural, scientific exchange could, for example, realize a form of study based on cultural dialogue and peace pedagogy.

\subsection{Tasawwuf Philosophy and Curriculum of Religious Instruction}

The epistemological, pedagogical, ethical and anthropological ideas discussed in the previous section are of worthwhile consideration in the following description of the content and objectives of religious and ethics instruction. Tasawwuf as a course of education describes humanity as the most capable of God's creatures both functionally and ontologically. Throughout the intensive master-student as well as self-education process, an individual shall be prepared morally and intellectually for this title. At the level of educational praxis, Sufism and its institutions occupy a significant role in the history of Islamic education. This article addresses the question of whether Tasawwuf as educational concept and practical tradition receives attention in the religious instruction of today's schools. A discussion of whether and how Tasawwuf as an educational entity is considered in current religious education follows. In order to answer the previous questions concretely and with the aid of an example, I will proceed with a relevant analysis of the curriculum of the religious and ethics courses of Turkish secondary schools (High Schools, namely Lise). Said religious instruction, in which specific moral (Ahlak) themes play a role, has the denomination "Religious Culture and Ethics" (Din Kültürü ve Ahlak Bilgisi), and is taught in the ninth through twelfth grades. These grades belong to those of the secondary schools in the Turkish school system. The combined religious and ethics instruction is divided into the following fields [21]:

1. Faith

2. Religious Service

3. The Prophet Muhammad (pbuh)

4. Revelation (wahy) and Reason

5. Morals and Values

6. Religion and Laicism

7. Religion, Culture and Civilization

The previous fields develop and broaden within various subtopics. Within these fields, it is possible not only to bear witness to religious and moral themes, but also to the official social- and religious-political premises of the Turkish republic. 
Table 1. Themes of the secondary school (High Schools, namely Lise) course: "Religious Culture and Ethics" [21]

\begin{tabular}{|c|c|c|c|c|}
\hline Fields & $\begin{array}{l}\text { Topics for } \\
\text { Grade } 9\end{array}$ & $\begin{array}{l}\text { Topics for } \\
\text { Grade } 10\end{array}$ & $\begin{array}{l}\text { Topics for } \\
\text { Grade } 11\end{array}$ & $\begin{array}{l}\text { Topics for } \\
\text { Grade } 12\end{array}$ \\
\hline Faith & $\begin{array}{l}\text { Humanity and } \\
\text { Religion }\end{array}$ & Belief in God & $\begin{array}{l}\text { Man and his Fate } \\
\text { (Qadar) }\end{array}$ & $\begin{array}{l}\text { Earthly Life and Life after } \\
\text { Death }\end{array}$ \\
\hline Religious Service & $\begin{array}{c}\text { Cleanliness and Service } \\
\text { to God }\end{array}$ & $\begin{array}{l}\text { Ibadat (Worship) } \\
\text { in Islam }\end{array}$ & $\begin{array}{c}\text { Principles and } \\
\text { Benefits of Ibadat } \\
\text { (Worship) in Islam }\end{array}$ & $\begin{array}{l}\text { Repentance and } \\
\text { Forgiveness }\end{array}$ \\
\hline $\begin{array}{c}\text { The Prophet } \\
\text { Muhammad (pbuh) }\end{array}$ & $\begin{array}{c}\text { The Life of } \\
\text { the Prophet } \\
\text { Muhammad (pbuh) }\end{array}$ & $\begin{array}{c}\text { The Prophet } \\
\text { Muhammad (pbuh) } \\
\text { according to the Koran }\end{array}$ & $\begin{array}{l}\text { The Exemplariness } \\
\text { of the Prophet } \\
\text { Muhammad (pbuh) }\end{array}$ & $\begin{array}{l}\text { Understanding the Prophet } \\
\text { Muhammad (pbuh) }\end{array}$ \\
\hline $\begin{array}{c}\text { Revelation (Wahy) } \\
\text { and } \\
\text { Reason }\end{array}$ & $\begin{array}{c}\text { The Koran } \\
\text { and its } \\
\text { Primary Themes }\end{array}$ & $\begin{array}{c}\text { The Koran } \\
\text { and its } \\
\text { Interpretations }\end{array}$ & $\begin{array}{l}\text { Interpretation in } \\
\text { Islamic Thought }\end{array}$ & $\begin{array}{c}\text { Tasawwuf-Oriented } \\
\text { Interpretations in Islamic } \\
\text { Thought }\end{array}$ \\
\hline $\begin{array}{c}\text { Morals and } \\
\text { Values }\end{array}$ & Values & $\begin{array}{l}\text { Rights, Liberties } \\
\text { and Religion }\end{array}$ & $\begin{array}{l}\text { Family and } \\
\text { Religion }\end{array}$ & $\begin{array}{l}\text { Islam and } \\
\text { Peace }\end{array}$ \\
\hline $\begin{array}{l}\text { Religion and } \\
\text { Laicism }\end{array}$ & $\begin{array}{l}\text { Laicism and } \\
\text { Religion }\end{array}$ & $\begin{array}{l}\text { Atatürk and } \\
\text { Religion }\end{array}$ & $\begin{array}{l}\text { Religious Service } \\
\text { in the Era of } \\
\text { Atatürk and of the } \\
\text { Republic }\end{array}$ & $\begin{array}{l}\text { Atatürk and } \\
\text { Religious } \\
\text { Education }\end{array}$ \\
\hline $\begin{array}{c}\text { Religion, Culture } \\
\text { and } \\
\text { Civilization } \\
\end{array}$ & $\begin{array}{l}\text { Islam and the } \\
\text { Turks }\end{array}$ & $\begin{array}{l}\text { Islam and } \\
\text { Science }\end{array}$ & $\begin{array}{l}\text { Islam and } \\
\text { Aesthetic }\end{array}$ & $\begin{array}{l}\text { Lived Religions and Their } \\
\text { Commonalities }\end{array}$ \\
\hline
\end{tabular}

The content relevant to Tasawwuf is only explicitly addressed in the $12^{\text {th }}$ grade within the topic Tasawwuf-Oriented Interpretations in Islamic Thinking. This subject focus, or topic area, accounts for $17 \%$ of the total subject matter of the $12^{\text {th }}$ and final grade of the general and vocational secondary schools (Lise) [21]. In the context of said topic area, the historic development of Sufic thought, Sufic perception, the relationship between God and man, Sufi-influenced views on morality, the fundamental Sufic Order in Anatolia (Yasawiya, Mawlawiya, Naqshibandiya, Qadiriya, Bektashiya and Alevism, Nusayriya), and the cultural of social cohabitation will be addressed.

In order to somewhat satisfy the expectations of the Alevis and Bektashis as non-Sunni paths, the religious sites and actions of these groups are included in the curriculum as subtopics of the previous subject areas. These subtopics are: Jam (Cem) and Jamhouse (Cemevi); implementation of Jam (Cem); Semah (worshipful dance action); fraternization act in the Alevi community (Müsahiplik); invocation (Dua); liturgical prayer (Gülbenk); and the month of mourning, Muharrem, along with Ashura (the day of martyrdom of the Imam Husain). Finally, the topic area Tasawwuf-Oriented Interpretations in Islamic Thought is rounded off with the theme Culture of Cohabitation and Tolerance [21]. The learning objectives of these subjects of instruction are formulated as follows [21]:

1. Explanation of the cause and emergence of various Sufi interpretations

2. The relationship between God and all beings is described as creator and creation

3. Comprehending the meaning of morality in Tasawwuf

4. Perceiving the Yasawiya, Mawlawiya, Naqshibandiya, Qadiriya, Bektashiya and Alevism as Sufic paths

5. Introduction to the presentation and nature of the Jam (Cem) ceremony
6. Defining the terms Samah (worshipful ritual movement), Musahiplik (fraternization act of the Alevite community) and Gülbenk (Prayer)

7. Sensing the meaning of the month Muhurram and day of Ashura in society

8. Introduction to Nusayriyah (Syrian Alevism)

9. Creation of consciousness of cohabitation and tolerance in Tasawwuf thought and deed

10. Understanding various Islamic interpretations in Islamic thought as the richness and pluralism of the religion

Despite the informative treatment of Tasawwuf, the attainment of purity and religiously-influenced intellectuality and its significance in Tasawwuf is not declared a curricular competence. The secondary school curriculum makes no reference to the anthropological and epistemological thought of Tasawwuf, although there are fitting areas for it in the curriculum as outlined, for example: Humanity and Religion (see previous table, Grade 9). The contents of the desired learning outcomes within the subject Humanity and Religion [21] could make good use of the Sufi-influenced pedagogical concept "al-insān al-kāmil" (the person seeking wholeness). This concept describes an individual's process of evolution along the path seeking scientific, mental, religious and moral perfection $[25,6]$. The subject The Koran and its Interpretations (Grade 10) also lacks mention of interpretations of the Koran according to Sufic influence [21]. Tasawwuf hermeneutics of the Koran, as well as the practical interpretation of the example of the living environment the Sufis provide, should be incorporated into the $11^{\text {th }}$ Grade subject Interpretation in Islamic Thought [21]. In the religion and ethics course curriculum of secondary schools titled "Religious Culture and Ethics," the terms shaped by Sufism, including Irshad (guidance), Zikr (commemoration of God) and Tafakkur (commemoration of 
God) are neither present as content material or educational goal.

\subsection{Sufism as a Form of Islamic Spirituality for the Classroom: Didactic and Content-related Recommendations}

While the learning and experiencing Sufism in all its manifestations is not to be expected in schools, it is possible to support the development of an individual spirituality in part by demonstrating the experiences of others. For this reason, it can be useful to discuss the divine experiences and intellectual thoughts of Sufi scholars/masters in school classrooms. For example, the instructor can begin a dialogue around the question of why the famous Sufi Mawlānā Ğalāl ad-Dīn Muhammad ar-Rūmī referred to the day of his death as the "wedding night (Shab-i Arus)". In such a reference, God is simultaneously considered the recipient and source of love. Death in this case is to be understood as an encounter with the beloved (God), and as the gateway to the experience of his mercy and glory. This discussion could open the way to a perception of God as both the Loving $(a l-W a d \bar{u} d)$ [Koran, 11: 90] and beloved, as well as the Compassionate (ar-Rahmān) [Koran, 59: 22]. The previous allegorical / symbolic expression of ar-Rūmī can serve as the starting point for the spiritual accentuation of theological and philosophical conversations with students. Accordingly, the diverse stories and parables of the Sufis [30] are appropriate narrative learning materials for teaching as they yield a variety of subjects for various religious themes. The biographies of Sufis who may stand as role models of virtue provide an abundance of scenes through which to depict the realisation of values and thus is suited as teaching material for values education.

Spiritual education as a series of processes of subject formation [32] is more than the mediation of religious and ethical knowledge; it is both an emotional formation and means of conscience development. Within the classroom, the treatment of spiritual attitudes such as attention and awareness, which hold as incisive values of the religious paths of piety and morality, elicits an emotional opening. Students can designate words to their own experiences related to awareness and attention, and describe the emotions connected to these events. Attention and awareness include tender care, appreciation and recognition [26]. The attention and awareness filled with such content stands for consideration as a spiritual ability leading to a dignified posture toward one's animate and inanimate surroundings. The conscious perception of the named spiritual states (attentiveness and awareness) means both a development of feeling and sensitisation (development of a conscious) for environmental protection and human rights, topics that are to be classified within religious and ethics instruction.

Administering content analysis of the terms central to the Tasawwuf (Sufism) and demonstrating their relationship to certain ideals and actions is to be considered a form of spiritual education. Toward this goal we select the term "Ihsan," already previously discussed in depth, as an example: Ihsan briefly means to execute every action as though God himself were a witness. The instructor can direct the following questions to their students for the purpose of discussion within class:

How can Ihsan consciousness influence the actions of those individuals who hold it?

Can Ihsan morally qualify human deeds?

Have you ever (as directed to the students) experienced a moment in which you felt God with you?

The previous questions could not only be verbally discussed; they could also be answered in writing or depicted in the form of an image (for example in a visual representation of the experiential moment implied by the third question).

Apart from the previous practical examples for classroom instruction, many possibilities exist for experiencing and studying the spiritual apart from a strictly curricular context, including visits to spiritually significant locations, observance of Sufi ceremonies (including chants and dances) and worship services (zikr) in Tekkes (sites of order in Sufism), or pedagogically conceived discussions with Sufi-minded individuals. These extracurricular opportunities can be considered forms of direct learning in authentic locations of life and learning among individuals practicing Sufism. All of these instances contribute to an improved and mature understanding of spirituality.

\section{Conclusions}

\subsection{Conclusions for Religious and Moral Pedagogy}

The practical and theoretical interpretations of Sufism demonstrate a non-denominational perspective. Sufism emphasizes the spiritual and ethical, rather than normative, side of Islam. It is from this spiritual side that commonalities of the Islamic confessions appear, while the normative side of Islam reveals the conventions of religious practice and legal issues that are often interpreted in a variety of ways. The embedding of themes relevant to Sufism within Islamic religious lessons qualifies this instruction as non-denominational.

Viewing Sufism as an intellectual and internal processing of religious and moral conviction offers answers to existential questions including: Who am I as an individual and what is my relationship to God? What are my responsibilities to my fellow human beings and our shared world? How can I orient myself within the universe? What is perfection and how is it attainable? Such questions are shaped by Sufism and offer students of religious and ethics studies opportunities to philosophize and theologize.

The Sufis often interpret the Koran and the Sunna (the teachings and deeds of the prophet) from a teleological perspective and designate this characterization as divine 
inspiration (ilhām or išăra). Accordingly, they make use of the symbolic language and strive to reveal the deeper, encoded meaning (ba titin) of the Koran. It is a form of pedagogical enrichment to make such interpretation available to students within religious education.

The reading of texts by Sufi scholars in the classroom offers students the opportunity to discover their own spiritual experiences and religious feelings, and to express these in words. These texts supply them with an intellectual basis and fitting vocabulary, which ultimately serves the development of personal religious and spiritual identity.

Sufi-appraised theology primarily emphasizes God's attributes as the All Merciful (ar-Rahmān), the Loving $(a l-W a d \bar{u} d)$, the Forgiving ( $a l-A f u w w)$, the Peace and the Blessing (as-Salām) and the Compassionate (al-Halìm). Understanding this theological emphasis as a tenet of Islamic religious instruction contributes to an understanding of Islam as a religion of love and peace. Such a view constitutes the theological foundation for values education.

\subsection{Conclusions for Curriculum Development: Clarification with the Aid of Turkish Secondary School Curriculum for Religious and Ethics Instruction}

Tasawwuf as Islamic-influenced educational tradition, piousness, intellectuality and way of life maintains a significant role in the history of Islamic civilization. Its school of thought and religious and cultural presence should, in denomination-oriented religious courses, receive appropriate attention. The relevant committees of the Turkish "Ministry for National Education" responsible for curriculum and the course "Religious Culture and Ethics" should take into consideration this prospect in the formation of the framework for the previously indicated course. The commission regularly includes theologians and religious pedagogues who could incorporate Tasawwuf-relevant themes into the pertinent program regarding both factual and religious educational endeavors.

Tasawwuf philosophy contributes to the formation of Islamic morality in both its school of thought and lifestyle, inhabiting a notable roll in the intellectual and practical interpretation of the Koran and the Sunna. As far as interpretation of the Koran, the Sufis gravitate toward the pursuit of a deep, symbolic and teleological analysis of the revelation of the Koran, as well as the ethical, internalized observance of the Sunna.

The strong moral emphasis regarding the religiosity and subsequent worshipful and educational acts as endeavors in the attainment of perfection is regarded as exceptional features of the way of Tasawwuf. These features should receive their appropriate recognition, particularly among the teaching content and educational objectives at the upper grade levels. It is of subsequent importance that young people also have the ability to recognize and critically reflect upon some irrational, esoteric, magic and syncretic aspects of thought and environment arising out of some directions of Sufism.

Christian religious instruction also takes seriously the relevant religiosity that occurs outside of the walls of the church [13]. The Sufi-minded religiosity oversteps the boundary of the Islam's confessional religiosity and reaches even those willing people outside of the mosque community. In this and various respects, Tasawwuf has earned a role as subject matter for Islamic religious instruction.

The curriculum analysis conducted for this article clearly demonstrates that Tasawwuf as learning content only rarely appears at all among the four grades $\left(9^{\text {th }}-12^{\text {th }}\right)$ of the secondary school (high school, namely Lise), despite the fact that Tasawwuf reflects the denominational diversity of Anatolia in the deepest sense.

Tasawwuf formulates rich educational goals, including Tazkiyya (tazkiya: the purification of the heart [6], Tafakkur (tafakkur: intellectual understanding [6], Taqwa (taqwā: fear of God, also in the sense of respect for the rights of God and creation), Irfan ( irfān: recognition and experience), Hikma (hikma: profound and diverse knowledge of existences, occurrences and circumstances), etc. These and other aims are not suitably addressed in the analyzed curriculum.

The students should be duly aware of the religious and ethically-relevant systems of Tasawwuf thought, interpretation and activity. Tasawwuf further offers a human-centered and intensely personal educational method. It possesses abundant scholarly philosophies as a traditional educational establishment of over one thousand years. Such philosophy and experience are worthy of a constructive broaching of the issue and reflection of religious and ethics courses, as they can provide approaches for the development and advancement of authentic Islamic educational thought and practice.

\section{REFERENCES}

[1] Abū Dāwūd, Sulaymān Ibn al-Ašcat. Kitāb as-Sunan (standardised Hadith Work).

[2] Berg, B. L., Lune, H. (2015). Sosyal Bilimlerde Nitel Araştrıma Yöntemleri. Transl. H. Aydın et al., $8^{\text {th }}$ Edition, Konya: Eğitim.

[3] Braun, R. (2008). Fitra und Fides -Glaubensvergewisserung und Alteritätsdenken im muslimischen Dialog mit dem Christentum. Retrieved 8 March, 2016 from https://opus4.kobv.de/opus4-fau/oai/container/index/docId/8 92.

[4] Buhārī, Muḥammad Ibn 'Ismā̄êll. Ağ-Ğāmic aṣ-Ṣahḥ̄ḥ (standardised Hadith Work).

[5] Büyüköztürk, Ş. et al. (2009). Bilimsel Araştırma Yöntemleri. $3^{\text {th }}$ Edition. Ankara: Pegem.

[6] Cebecioğlu, E. (1997). Tasavvuf Terimleri ve Deyimleri Sözlü̆̆̈̈. Ankara: Rehber. 
[7] Cinar, H. I. (2009). Die islamisch-mystische Koranexegese (at-tafsīr al-išārī) im Überblick. Journal of Religious Culture, 2009 (127). Retrieved 14 April, 2016, from http://www.irenik.org/uploads/pdf/a101218172826636.pdf.

[8] Fārābī, Abū Nașr Muhammad [Farabi] (2001). El-Medinetü'l Fâzula [Mabādi' ārā' ahl al-madīna al-fāḍila]. Trans. N. Danışman, Akara: M.E.B.

[9] Ġazzālī, Abū Hāmid Muhammad b. Muḥammad [İmam Gazâlî] (2004). Mü'minler Iç̧in Yükselme Basamakları. Ed. A. Duran, Istanbul: Hikmet.

[10] Ğurḡānī Alī Ibn-Muhammad (2014). Ta rî̀fât [Ta rîfât: Tasavvuf Istılahları]. Arabic Text with Turkish Translation. Trans. A. M. Tolun, Ed. Abdulrahman Acer, Istanbul: Litera.

[11] Günes, M. (2012). Begriffliche Entwicklung des Sufismus. Journal of Religious Culture, 2012 (158). Retrieved 14 April, 2016 from www.uni-frankfurt.de/irenik/relkultur158.pdf.

[12] Hemel, U. (2009). Religiöse Kompetenz als Ziel des Religionsunterrichts. Retrieved 25 March, 2016 from http://institut-fuersozialstrategie.de/wpcontent/uploads/2015/ 05/rel_vortrag_religioese_kompetenz.pdf.

[13] Husmann, B. (2009). Zentrum und Peripherie. Das gymnasiale Kerncurriculum Ev. Religion 5-10. Loccumer Pelikan, 09 (3), 110-114.

[14] Hünkâr Hac1 Bektâș-1 Velî (2007). Serh-i Besmele [Besmele Tefsiri]. Ottoman-Turkish Text with New-Turkish Version, Ed. Hamiye Duran, Ankara: Diyanet İşleri Vakfi.

[15] Ibn 'Arabī, Muhyi-d-Dīn al-Hātimī [or 'Abdallāh Ibn Mas'ūd al-Balyān̄̄] (2014). Nefsini Bilen Rabbini Bilir [Risāla at-Tawhìd]. Trans. and Comment. M. E. Erbili, $4^{\text {th }}$ Edition, Istanbul: hayykitab.

[16] Ibn 'Arabī, Muhyi-d-Dīn al Hātimī (n.d.). Fuṣ̄̄s al-Hikam. Beirut: Dār al-Kitāb al-'Arabī.

[17] Ibn Sīnā, al-Husain Ibn 'Abdullāh (2005). Al-Išāāāt wa-t-tanbīhāt [i்şaretler ve Tembihler]. Arabic Text with Turkish Translation, Trans. A. Durusoy, M. Macit \& E. Demirli, Istanbul: Litera.

[18] Ibn Sīnā, al-Husain Ibn 'Abdullāh [İbn-i Sîna] (2011). As-Sa āda wa-l-Huğa ğal- 'Ašara 'alā an an-Nafs al-Insānīya Ğawhar [Mutluluk ve İnsan Nefsinin Cevher Olduğuna İliskin On Delil]. Arabic Text with Turkish Translation, Ed. \& Trans. F. Toktaş, Ankara: Türkiye Diyanet Vakfi.

[19] Ihwān aș-Șafa' [İhvân-1 Safâ] (2013). İhvân-ı Safâ Risâleleri [Rasāil Ihwān aș-Ṣafă wa-Hullān al-Wafā]. Ed. A. Kahraman, Trans. İ. Çalışkan et al., Vol. 2, Istanbul: Ayrıntı.

[20] Koch, L. (2014). Zwischen Moral und Religion. In Behr, H. H. \& Ulfat, F. (Ed.), Zwischen Himmel und Erde. Bildungsphilosophische Verhältnisbestimmung von Heiligem
Text und Geist, (pp. 107-120). Münster \& New York: Waxmann.

[21] M.E.B. (2010): Milli Eğitim Bakanlı̆̆ı Din Öğretimi Genel Müdürlüğü (Ed.) (2010). Ortaöğretim Din Kültürü ve Ahlak Bilgisi Dersi (9, 10, 11 ve 12. Sinıflar) Öğretim Programı. Anakra: M.E.B.

[22] Meriam, S. B. (2013). Nitel Araștırma. Desen ve Uygulama İçin Bir Rehber - Qualitative Research. A Guide to Design and Implementation: Trans. S. Turan et al., Ankara: Nobel.

[23] Molla-Djafari, H. (2001). Gott hat die schönsten Namen... wa-lillāhi-l-asmāù-l- husnā...Islamische Gottesnamen, ihre Bedeutung, Verwendung und Probleme ihrer Übersetzung. Frankfurt am Main etc.: Peter Lang.

[24] Muslim Ibn al-Ḥağğāğ. Ağ-Ǧāmic aṣ-Ṣāḥ̄ị̣ (standardised Hadith Work).

[25] Nasafī, Nağm ad-Dīn Abū Hafṣ 'Umar Ibn Muhammad [Azizuddin Nesefî] (2013). Tasavvufta Insan Meselesi: İnsan-l Kâmil [Kitāb al-Insān al-Kāmil]. Trans. M. Kanar, $2^{\text {nd }}$ Edition, Istanbul: Dergah.

[26] Peng-Keller, S. (2015). Achtsamkeit als spiritueller Leitbegriff. Annäherungen aus spiritualitätsgeschichtlicher und theologischer Perspektive. Rellis, 16 (2), 4-7, 4.

[27] Polat, M. (2010). Menschen als ,Kalifen Gottes auf Erden'. Eine sinnanthropologische und religionspädagogische Betrachtung. Religionspädagogische Beiträge, 2010 (65), 77-83.

[28] Polat, M. (2010a). Religiöse Mündigkeit als Ziel des islamischen Religionsunterrichts. In M. Polat \& C. Tosun (Ed.), Islamische Theologie und Religionspädagogik. Islamische Bildung als Erziehung zur Entfaltung des Selbst, (pp. 185-201). Frankfurt a. M. etc.: Peter Lang.

[29] Rothgangel, M. (2009). Grundlegende Aspekte kompetenzorientierter Religionspädagogik. Loccumer Pelikan, 2009 (3), 103-106.

[30] Rûmî, M. C. [Mawlānā Ğalāl ad-Dīn Muhammad ar-Rūmī] (2013). Mesnevi [Masnawī]. Trans. D. Örs \& H. Kırlangıc, $3^{\text {th }}$ Edition, Konya: Konya Büyükşehir Belediyesi.

[31] Schimmel, A. (2014). Sufismus. Eine Einführung in die islamische Mystik. $5^{\text {th }}$ Edition, München: C.H.Beck.

[32] Wappowa, J. (2015). Ein besonderer Modus der Weltbegegnung? Spirituelle Bildung und spirituelles Lernen in der Schule. Rellis, 16 (2), 20-23, 20.

[33] Yıldırım A., Şimşek H. (2011). Sosyal Bilimlerde Nitel Araștırma Yöntemleri. $8^{\text {th }}$ Edition, Ankara: Seçkin.

[34] Yunus Emre (2012). Risâletü'n-Nushiyye. Ed. Erdoğan Boz. Ankara: Gazi. 